\title{
Electrical conductivity of a locked fault: investigation of the Ganos segment of the North Anatolian Fault using three-dimensional magnetotellurics
}

\author{
Mustafa Karaş ${ }^{1,2}$, Sabri Bülent Tank ${ }^{1 *}$ and Sinan Özaydın ${ }^{1}$
}

\begin{abstract}
This study attempts to reveal the fault zone characteristics of the locked Ganos Fault based on electrical resistivity studies including audio-frequency (AMT: 10,400-1 Hz) and wide-band (MT: 360-0.000538 Hz) magnetotellurics near the epicenter of the last major event, that is, the 1912 Mürefte Earthquake $\left(M_{w}\right.$ 7.4). The AMT data were collected at twelve stations, closely spaced from north to south, to resolve the shallow resistivity structure to $1 \mathrm{~km}$ depth. Subsequently, 13 wide-band MT stations were arranged to form a grid enclosing the AMT profile to decipher the deeper structure. Three-dimensional inverse modeling indicates highly conductive anomalies representing fault zone conductors along the Ganos Fault. Subsidiary faults around the Ganos Fault, which are conductive structures with individual mechanically weak features, merge into a greater damage zone, creating a wide fluid-bearing environment. This damage zone is located on the southern side of the fault and defines an asymmetry around the main fault strand, which demonstrates distributed conduit behavior of fluid flow. Ophiolitic basement occurs as low-conductivity block beneath younger formations at a depth of $2 \mathrm{~km}$, where the mechanically weak to strong transition occurs. Resistive structures on both sides of the fault beneath this transition suggest that the lack of seismicity might be related to the absence of fluid pathways in the seismogenic zone.
\end{abstract}

Keywords: Fluid, North Anatolian Fault, Ganos Fault, Fault zone conductor, Locked fault, Electrical resistivity, Asymmetric damage zone, Magnetotellurics

\section{Introduction}

The Ganos Fault is an active segment representing a seismic gap at the western end of the 1200-km-long dextral North Anatolian Fault (NAF; Şengör et al. 2005). In Northwest Anatolia, the NAF exhibits a relatively complex structure; it partitions into several active branches as it enters the Marmara Sea near İzmit. The northernmost strand exits the sea near Gaziköy, Tekirdağ, before it enters the Saros Bay. This particular 45-km-long segment is known as Ganos Fault (GF) and generated the $M_{\mathrm{w}}$ 7.4 Şarköy-Mürefte Earthquake in 1912 (Ambraseys

\footnotetext{
*Correspondence: bulent.tank@boun.edu.tr

${ }^{1}$ Kandilli Observatory and Earthquake Research Institute, Boğaziçi

University, İstanbul, Turkey

Full list of author information is available at the end of the article
}

and Finkel 1987; Ambraseys 2002). Major activities along the NAF had the tendency to propagate from east to west due to the generation of periodical seismic events with centennial cycles (Parsons et al. 2000; Sengör et al. 2005). Following the disastrous 1999 İzmit and Düzce earthquakes, the geoscience community reached a consensus that the next significant event is expected in the western part of the NAF, particularly related to segments within the Marmara Sea and/or GF (Şengör et al. 2005).

The GF was previously examined using geological, geodetic, and seismological tools (Okay et al. 1999; Rockwell et al. 2001; Yaltırak and Alpar 2002; Okay et al. 2004; Seeber et al. 2004; Motagh et al. 2007; Janssen et al. 2009; Okay et al. 2010; Özcan et al. 2010; Öztürk et al. 2015) to decipher its tectonic evolution, morphological and structural properties, and fault-fluid relations. 
However, the detailed electrical resistivity structure of this segment is unknown due to the lack of comprehensive investigations.

Magnetotellurics (MT) is capable of providing satisfying results to reveal the shallow and deep electrical properties of active and fossil fault zones (Unsworth et al. 1997; Bedrosian et al. 2002, 2004; Becken et al. 2008, 2011; Wannamaker et al. 2009; Meqbel et al. 2016). The MT method is a geophysical tool that uses naturally occurring electromagnetic fields to decipher the electrical properties of the subsurface (Vozoff 1972; Kaufman and Keller 1981; Jiracek 1995). Saline fluids, brines, meteoric water, metamorphic fluids, and partial melts favor ionic transfer and enforce fluid interconnection within the crust and upper mantle that can be identified using the MT method (Becken and Ritter 2012). The pore fluids drastically enhance the electrical conductivity, making the MT method suitable for investigations in the vicinity of fault zones (Unsworth and Bedrosian 2004). A second mechanism suggests the transfer of electrical currents via electronic transfer in metallic ores (such as graphite and sulfides; Jödicke 1992).

The mechanism behind fracturing processes is influenced by the presence of hydraulic conduits because fluid invasion affects the rheological properties of upper crustal structures ranging from fissured rocks to large faults (Zhang et al. 2002). The intrusion of fluids into fault zones changes the effective normal stress to a point at which new circumstances could induce seismicity by altering the rheological, chemical, and frictional properties of the region (Hickman et al. 1995). This mutual effect between seismicity and fluid intrusion triggers ongoing and evolving deformation, shaping the internal geometry of a fault zone, where fluid presence is constituted by structures with relevant permeability. While highly depending on the petrological properties of its protolith (Evans 1990), the spatial variations of the fault core and damage zone can be classified based on four endmember fault zone architecture styles: localized barrier, localized conduit, distributed conduit, and combined conduit-barrier. By fitting any physical example into this categorization based on the ratio of fault zone components, one can qualitatively describe the fluid flow behavior of the fault, which varies between these endmembers (Caine et al. 1996).

The MT method has been proven to be capable of imaging regions of high conductivity in the vicinity of fault zones called "fault zone conductors" (FZC; Unsworth et al. 1997, 1999, 2000; Bedrosian et al. 2002, 2004; Ritter et al. 2005; Becken and Ritter 2012). High conductivity of a fault zone was first observed for the Yamasaki Fault, Japan, by the "Electromagnetic Research Group for the Active Fault" (1982). Unsworth et al. $(1997,2000)$ made systematic MT observations to detect a potential conductive zone located on the partially (surface to $\sim 3 \mathrm{~km}$ ) creeping segment of the San Andreas Fault (SAF), north of Parkfield, California; they defined it as a FZC and linked it to saline fluid-bearing porous formations. According to Unsworth et al. (1997, 2000), these anomalous features near Parkfield do not coincide with seismic activity and advocate the fault-weakening behavior of fluids at such depths. Furthermore, the central creeping segment of the SAF at Hollister was also imaged with the MT method. The corresponding resistivity structures correlated well with the high $V_{\mathrm{p}} / V_{\mathrm{s}}$ ratios, which indicate fluid presence in a fault zone (Bedrosian et al. 2002, 2004). Moreover, another fluid invasion mechanism might trigger earthquakes, rather than provoke creeping motion within much greater depths, and consequently different rheological environments. Becken et al. (2011) subsequently pictured the highly conductive zone that is linked to dehydration of the serpentinite mantle wedge beneath the Parkfield and Cholame Region, where non-volcanic tremor events are concentrated. Lateral fluid pathways through the seismogenic zone of the SAF were interpreted as hydraulic fracturing caused by superhydrostatic pressure. This result complements that of previous studies, suggesting that the seismicity in Parkfield is fluid-driven (Thomas et al. 2009) and characterized by very precise recurring events (Johnson and McEvilly 1995). This points out the importance of determining the origin of the fluid flux (either meteoric or metamorphic; Irwin and Barnes 1975; Byerlee 1993). The MT studies in the vicinity of a locked fault showed high-resistivity structures on both sides of the fault, which correspond to mechanically strong formations (Unsworth et al. 1999; Goto et al. 2005). The previously observed FZCs of locked faults were relatively smaller compared with that of weaker faults, where their lateral conductance values at the direction perpendicular to the fault line appear smaller (Ritter et al. 2005). Unsworth et al. (1999) made such a direct comparison between the locked Carrizo Plain and Parkfield. Because the GF is known to be seismically inactive, one might expect attributes similar to the previous examples.

Here, we examine the electrical resistivity structure of the GF based on several data analysis techniques and modeling results to interpret the geological and rheological properties of the region. First, we describe the study area and data acquisition. Then, the results of dimensionality analyses and resistivity models will be reported to illustrate a new physical approach with respect to the area of interest.

\section{Study field and data acquisition}

Multiple MT studies were performed aiming to image electrical resistivity structures along the NAF (Honkura 
et al. 2000, 2013; Oshiman et al. 2002; Tank et al. 2003, 2005; Tank 2012; Türkoğlu et al. 2008; Kaya et al. 2009, 2013). In this study, the first magnetotelluric data that specifically focus on the Ganos Region were analyzed with three-dimensional numerical modeling routines. For a detailed picture of the area, the study was carried out using high-frequency data acquisition within short time intervals (2-3 h, AMT) and mid-range frequencies within relatively long time intervals $(18-27 \mathrm{~h}$, wide-band MT).

The northern branch of the NAF passes through the Marmara Sea and continues westward, appearing onshore beyond Gaziköy in Tekirdağ (Fig. 1a). This segment of the NAF in southern Thrace is known as the GF and extends toward the Aegean Sea before entering the Gulf of Saros (Rockwell et al. 2001). The GF has produced large earthquakes (e.g., October 18, 1343, and August 5, $1766)$ in the past; the last important event occurred near Mürefte in 1912 (Ambraseys 2002). Because there is a certain lack of seismicity, the fault can be considered as seismic gap, unable to produce salient events between earthquake cycles (Tüysüz et al. 1998; Janssen et al. 2009; Öztürk et al. 2015). Paleoseismological studies of the GF showed that the recurrence interval of the events with

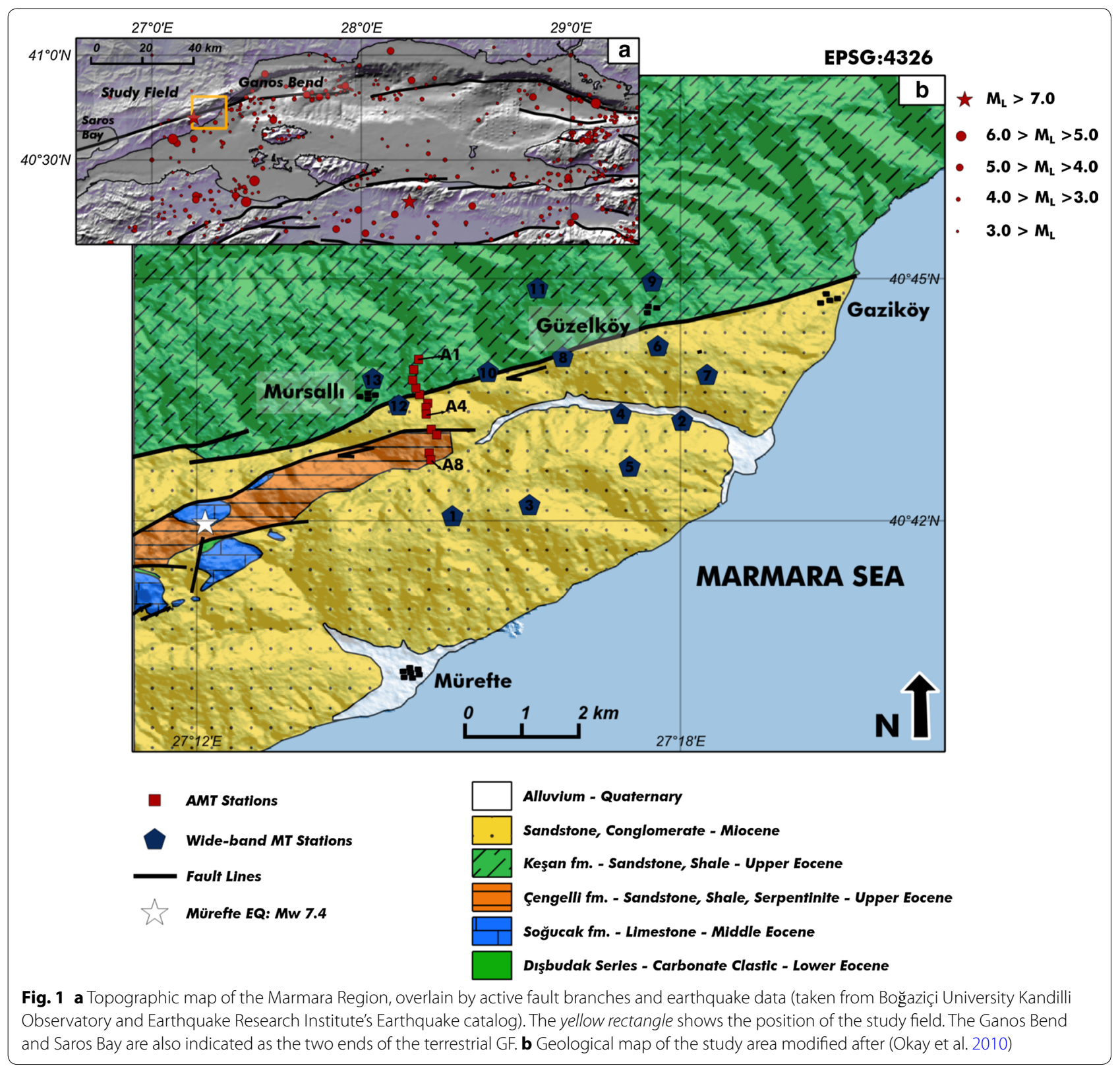


$M>7$ is $323 \pm 142$ years with an average coseismic slip rate of $5.25 \mathrm{~m}$ (Meghraoui et al. 2012). Motagh et al. (2007) created viscoelastic and elastic half-space models by designing inversion schemes based on geodetic data to determine the interseismic deformation pattern along the GF and estimated a locking depth of $\sim 8-17 \mathrm{~km}$ using both models, which is in good agreement with the observed seismicity (Janssen et al. 2009; Öztürk et al. 2015).

The GF runs parallel to the Ganos Mountain, which is the consequential uplift structure related to transpressional strain (Okay et al. 2004). The prominent geological features of the area are not only due to neotectonic activities caused by the NAF but also due to an evolutionary process that took place prior to the NAF (Zattin et al. 2005). In the late Pliocene, the fault system was activated as strike-slip fault when the stress regime of the NAF reached out west enough to capture the mechanically weak area, which is now known as GF. This crustal weakness might cause complex kinematic variations by defining an obliquity for the fault (Seeber et al. 2004). The change of the stress regime between the tectonic stages of the GF system created a favorable environment for shortening, which governed the uplift of the Ganos Mountain from Oligocene to mid-Miocene. Although the driving force of preceding events is not clear, it might be linked to the far-field stress regime caused by the IntraPontide subduction and rotation of the Anatolian Plate accommodated by Aegean subduction rollback (Zattin et al. 2005). The displacement vectors modeled based on geodetic measurements show that the obliquity of the GF is only $3^{\circ} \pm 1^{\circ}$ and that of the Western Central Marmara Fault is $14^{\circ} \pm 3^{\circ}$; the weak transpressive behavior changes to strong transtensive characteristics eastwards along the NAF. The link between the two deformation types is represented by the Ganos Bend, which rotates $\sim 17^{\circ}$ southwards in the fault plane moving westwards (Okay et al. 2004).

The stratigraphy of north and south of the GF also has different attributes, which are analogous to the tectonic setting described above. The Keşan Formation is the prominent stratum in the north consisting of Upper Eocene-Oligocene shale, sandstone, and siltstone intercalation representing the Ganos Mountain. On the other side of the fault (south), the Dışbudak series is present beneath the Çengelli and Soğucak formations; ophiolitic rocks constitute the basement. Another important geological feature is highly porous large mid-Miocene sandstone blocks that unconformably overly the EoceneOligocene units (Fig. 1b; Okay et al. 2010; Özcan et al. 2010).

Mursall is located near the southern side of the Ganos Mountain. The valleys between Mursallı and Gaziköy are the only places, where the fault trace could be observed (Yaltırak and Alpar 2002). The AMT and wide-band MT data of the GF were collected at twelve and thirteen stations that were arranged to form a continuous profile and a grid between Mursallı and Gaziköy, respectively (Fig. 1b). Two Phoenix Geophysics systems (MTU-5A) with compatible magnetic coils (MTC-30 and MTC-50) were utilized to record five-channel (Ex, Ey, Hx, Hy, and $\mathrm{Hz}$ ) AMT and wide-band MT data. The frequency ranges for AMT and wide-band MT were $10 \mathrm{kHz}-1 \mathrm{~Hz}$ and $360-0.000538 \mathrm{~Hz}$, respectively. Electric field measurements were taken with non-polarizing $\mathrm{Pb}-\mathrm{PbCl}_{2}$ electrodes with dipole lengths of approximately $50-60 \mathrm{~m}$. To achieve better-quality sounding curves, a remote reference technique was utilized (Gamble et al. 1979).

\section{Dimensionality}

Geological features of the Earth can be simplified in 2D, especially near tectonic boundaries; however, their 3D interpretations have to be acknowledged to achieve more realistic models. The Groom and Bailey (GB) decomposition (Groom and Bailey 1989) has been conventionally applied to the MT data to eliminate unwanted effects caused by near-surface galvanic distortions. The GB decomposition partly solves the distortion problem by separating the effects into determinable (shear and twist) and indeterminable parts (site gain and anisotropy) and removes the determinable part to allow the calculation of geoelectric strike angles (Groom and Bailey 1989). A statistically extended form of the GB decomposition method was implemented that can separately treat frequencies, sites, and profiles (McNeice and Jones 2001). With respect to the AMT dataset, the multisite-multifrequency approach yielded an average geoelectric strike angle of $\sim \mathrm{N} 69^{\circ} \mathrm{E}$. For this approach, data corresponding to frequencies $>2500 \mathrm{~Hz}$ were identified as irrelevant for the determination of the geoelectric strike direction at seismogenic fault depths and thus excluded from the analysis of strike angles.

Another way of examining the dimensionality of MT data is to perform magnetotelluric phase tensor analyses developed by Caldwell et al. (2004). Phase tensor analyses have the advantage of providing distortion-free dimensionality information. In this study, the phase tensor analyses results are presented in the form of rose diagrams and phase tensor ellipses (Figs. 2, 3). The phase tensor analyses of AMT data yield a strike direction of $\sim \mathrm{N} 70^{\circ} \mathrm{E}$ (Fig. 2a). While local features in the region principally affect higher frequencies, the lower frequencies corresponding to seismogenic depths $(100-0.01 \mathrm{~Hz})$ show an affinity toward the geoelectric strike that denotes the fault direction (Fig. 2b). All geoelectric strike directions derived from both GB-decomposed data and 


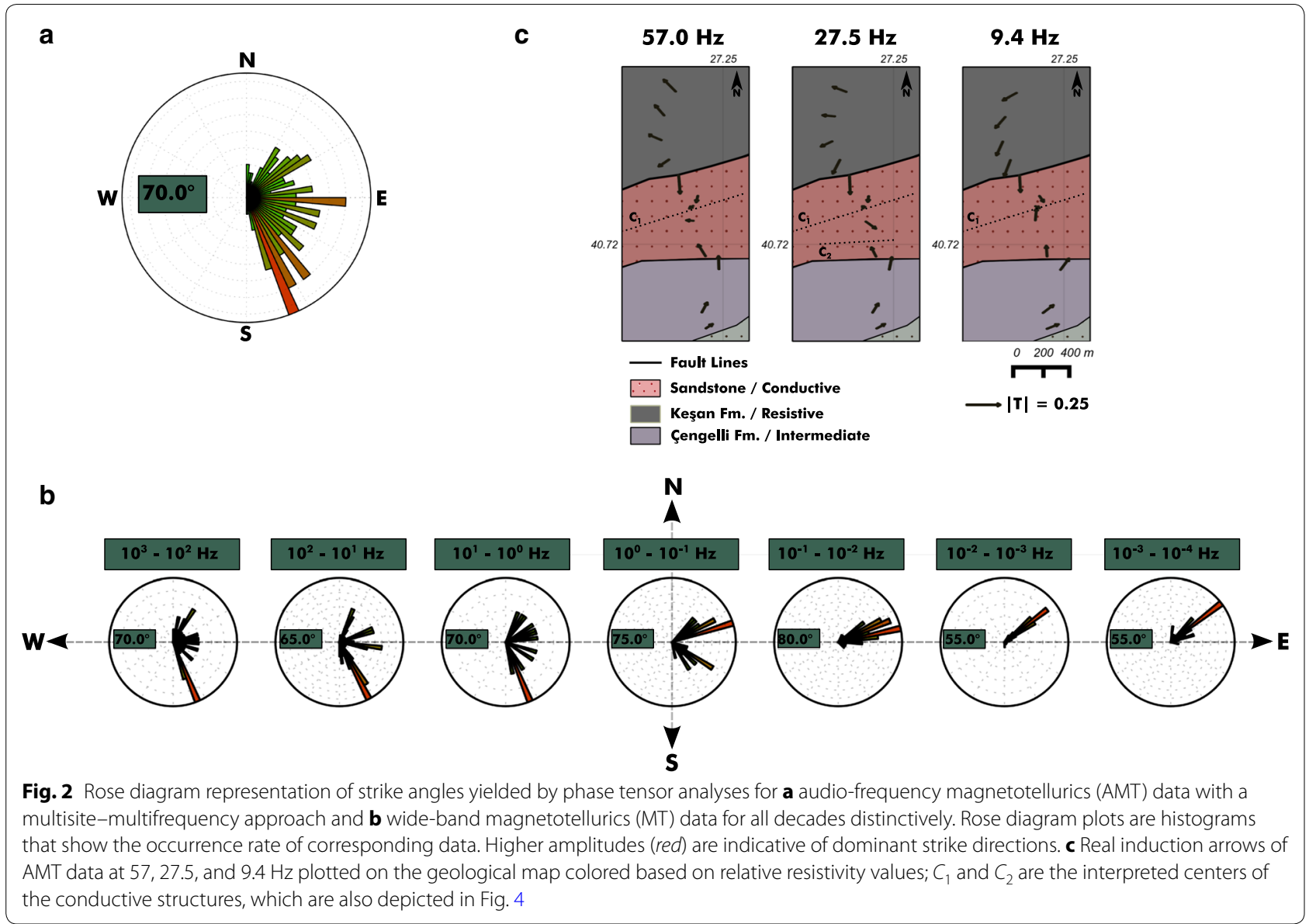

phase tensor analysis are in agreement with each other and complement the geological and seismological strike angles of the main fault (Okay et al. 2004; Seeber et al. 2004).

Graphical representations of phase tensors are given by ellipses; the major axis represents the polarization direction, and $\beta$ values (i.e., skew angles) provide essential dimensionality information (Caldwell et al. 2004). Extreme colors (dark red and dark blue) in these ellipses represent higher and lower $\beta$ values as indicator of threedimensionality. Figure 3 shows the phase tensor ellipses for $40,4.5,0.75$, and $0.141 \mathrm{~Hz}$. When the $\beta$ values of the wide-band MT data are examined for these frequencies, a highly three-dimensional electrical structure of the deeper parts becomes apparent, particularly $<0.2 \mathrm{~Hz}$. Station 10 is an exception; it demonstrates consistently high $\beta$ values at all examined frequencies.

Induction arrows are vector equivalents of complex ratios between horizontal and vertical magnetic field components also known as vertical transfer functions (i.e., tipper) (Parkinson 1959). The fault zones tend to get shorter within the conductive zones and diminish at the center of the conductor, while the resistive parts are represented by larger induction arrows (Ritter et al. 2005). In this study, the Parkinson convention is used for induction arrows; the real components of the arrows point to the conductor. For AMT data, Fig. 2c shows the real component of the induction arrows for selected frequencies $(57,27.5$, and $9.4 \mathrm{~Hz})$ at each station across the fault. Induction arrows north of the fault point S-SW, while arrows in the south have $\mathrm{N}-\mathrm{NE}$ directions. As portrayed in the classical description of induction arrows for the 2D Earth, decreasing magnitudes were observed on both sides with decreasing distance to the conductor. The behavior of induction arrows indicates the presence of a potential fault zone conductor in the middle of the profile (dashed lines in Fig. 2c).

The map view of real and imaginary induction arrows for all wide-band MT stations and three additional AMT stations is shown in Fig. 3 together with corresponding phase tensor results for the selected frequencies mentioned above. Because the induction arrows corresponding to frequencies $<0.1 \mathrm{~Hz}$ show an anomalous tenacity toward the Marmara Sea, one can easily conclude that the tipper data below this threshold are highly influenced by the coast effect (Fig. 3d). Above a frequency of $0.1 \mathrm{~Hz}$, 


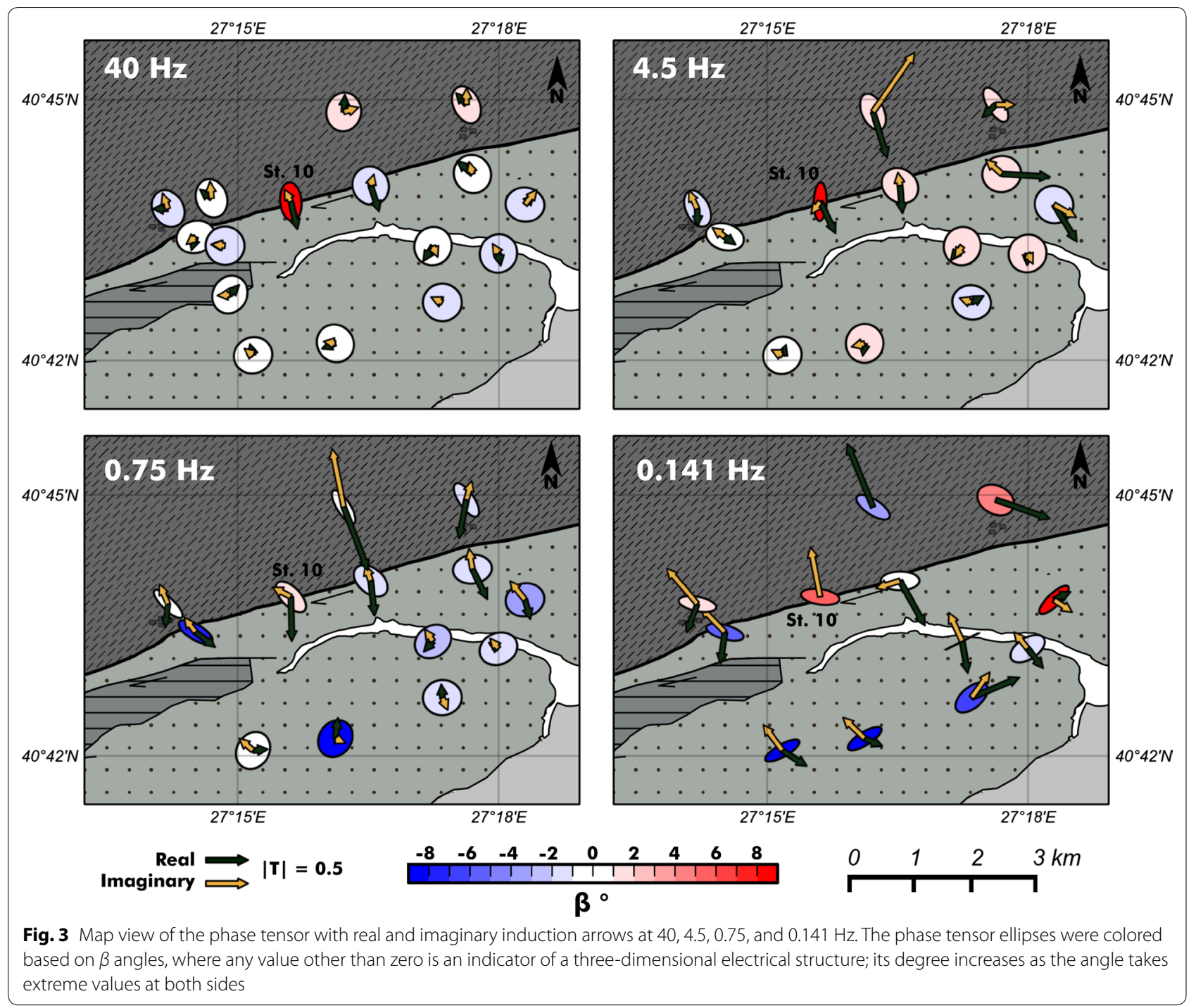

the real parts of the induction arrows show a consistent behavior; they point to conductive areas driven by the fault-related structures, suggesting that the FZC continues throughout the GF in the study area. The imaginary parts of the induction arrows in the vicinity of the fault are antiparallel to the real parts, thus supporting the idea of a $2 \mathrm{D}$ electrical elongation (Fig. 3b, c).

\section{Modeling}

Conventionally, the primary function of dimensionality analyses was to make assumptions for $2 \mathrm{D}$ magnetotelluric modeling. Because 3D modeling schemes have progressed rapidly over the last two decades, the purpose of these analyses shifted to understanding the physical essence of data. The 3D modeling has a great advantage with respect to overcoming ambiguities that are caused by $2 \mathrm{D}$ modeling assumptions; it has been proven to be more effective and accurate, even for profile-based measurements (Ledo 2005; Siripunvaraporn et al. 2005a; Patro and Egbert 2011; Siripunvaraporn 2012).

Following the dimensionality analyses, inversion of AMT and wide-band MT data was performed using code developed by Egbert and Kelbert (2012; ModEM). The ModEM algorithm is a 3D inversion algorithm that uses a nonlinear conjugate gradient (NLCG) scheme for the parameter search. This modular system is based on a finite-difference approach and discretizes the forward problem for numerical solution. The aim of ModEM is to minimize the penalty functional during the model update (Kelbert et al. 2014). In addition, the Jacobian of the mapping from model parameters to data is a key element of electromagnetic inversion methods; the ModEM 
factorizes the Jacobian into different components to reduce computational disadvantages (Egbert and Kelbert 2012). It can utilize the full impedance tensor (both real and imaginary parts) and tipper information.

The meshes were designed with evenly spaced 100 and $200 \mathrm{~m}$ grid nodes near the center of the study field; the mesh size was set to $39 \times 21 \times 37$ and $43 \times 45 \times 37$ including seven air layers for the AMT and wide-band MT data, respectively. Uniform initial models with homogeneous $100 \Omega \mathrm{m}$ electrical resistivity were used for both datasets; the thickness of the first layer of each model was set to 10 and $100 \mathrm{~m}$, respectively. The cell sizes were designed using a vertical increment factor of 1.3.

For AMT data, the code ran at three periods per decade (15 in total) and the error floor of all components for both diagonal and off-diagonal elements was $5.0 \%$ of $\sqrt{\left|Z_{x y} Z_{y x}\right|}$, for both diagonal and off-diagonal elements. The ModEM ran 22 iterations until the target RMS (root mean square) of 2.8 was acquired (Fig. 4).

The evaluation of wide-band MT data required more effort due to the larger data size (14 frequencies) and inherent coast effect (Parkinson 1959). To overcome the coast effect, the eastern and southern sides of the initial model were fixed to $0.3 \Omega \mathrm{m}$ cells representing the Marmara Sea. Similar to the AMT process, the error floors of all components for both diagonal and off-diagonal elements were chosen to be $5.0 \%$ of $\sqrt{\left|Z_{x y} Z_{y x}\right|}$, for both diagonal and off-diagonal elements. The run ended after 112 iterations by finalizing at a model with a RMS of 3.4 (Figs. 5, 6). In addition to the final RMS values, the model curves and data demonstrated good fits for both diagonal and off-diagonal impedances.

We used another program, WSINV3DMT (Siripunvaraporn et al. 2005b), and achieved consistent results (see Additional file 1).

\section{Sensitivity tests}

The validity of the FZC was tested on the final model using sensitivity tests. To determine the spatial dimensions of the FZC, the inversion responses after one iteration were calculated for four different cases with a deep resistive block (300 $\Omega \mathrm{m})$ starting at different depths (1380, 1080, 780, and $380 \mathrm{~m}$ ) of the base of the model. The installation of a resistive block at shallower depth, instead of conductive structures referring to FZC, caused the increment of the RMS values. The corresponding values are as follows: 1380 m, 3.42; 1080 m, 3.72; 800 m, 4.6; and $380 \mathrm{~m}, 7.77$. The model responses for these inversions are shown in Fig. 7 for two sites that are located above the anomalous region. In addition to the RMS values, fitting of the data clarified that the model is sensitive to the relevant anomalies and the conductor has a valid presence.

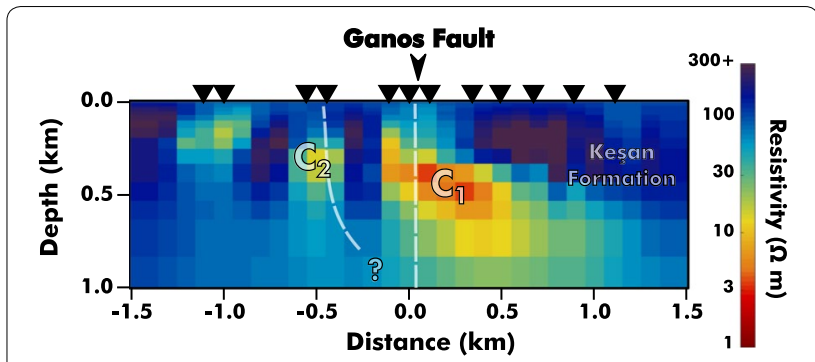

Fig. 4 Resistivity model obtained from the inversion of audio-frequency magnetotellurics (AMT) data. Black triangles show the station locations. Thick dashed lines indicate the fault locations. The $C_{1}$ and $C_{2}$ anomalies are the fault zone conductors of the main Ganos Fault and subsidiary oblique strike-slip structure in the south, respectively. The resistivity color scale is logarithmic

\section{Results and discussion}

This study reveals the electrical conductivity structure of the GF by using 3D modeling of both high-resolution AMT and wide-band MT data. The general geological consensus might include prima facie claims placing the potential fault line on the overt resistivity contrast. However, the induction arrows indicate the presence of an anomaly just south of the conductive-resistive interface, thus pointing out a more accurate location of the GF (Fig. 2c, 3) and supporting the idea of Bedrosian et al. (2004) and Ritter et al. (2005) who made implications with respect to vertical transfer function data and fault zones. Confirming this approach, the AMT model demonstrates a highly conductive $\mathrm{C} 1$ anomaly at the same location indicated by induction arrows (Fig. 4). This anomaly can be considered as FZC of the main fault, which has a width of $\sim 700 \mathrm{~m}$ and extends to a depth of $\sim 300 \mathrm{~m}$. The FZC retained from the AMT model has a lateral conductance value of $\sim 80 \mathrm{~S}$, while the value for the section based on the wide-band MT model of the same profile is $\sim 100 \mathrm{~S}$. The variation of the lateral conductance depends on the calculation, which is basically the width over the average resistivity of the FZC. The conductance values are used as practical measure of the rheological attributes of the relevant conductors; the conductors reflect fractured zones that are interconnected by fluid pathways. The given values of lateral conductance values and depth extent of the FZCs show that MT and AMT results complement each other in a way that the models fit previously described correlations between fault characteristics and FZC properties (Hoffmann-Rothe et al. 2004; Ritter et al. 2005). However, the wide-band MT models show that lateral conductance values calculated for different profile sections of the GF vary along the fault. The fluctuating lateral conductance values might be linked to the lightly consolidated and widely distributed Miocene sandstones south of the fault and 


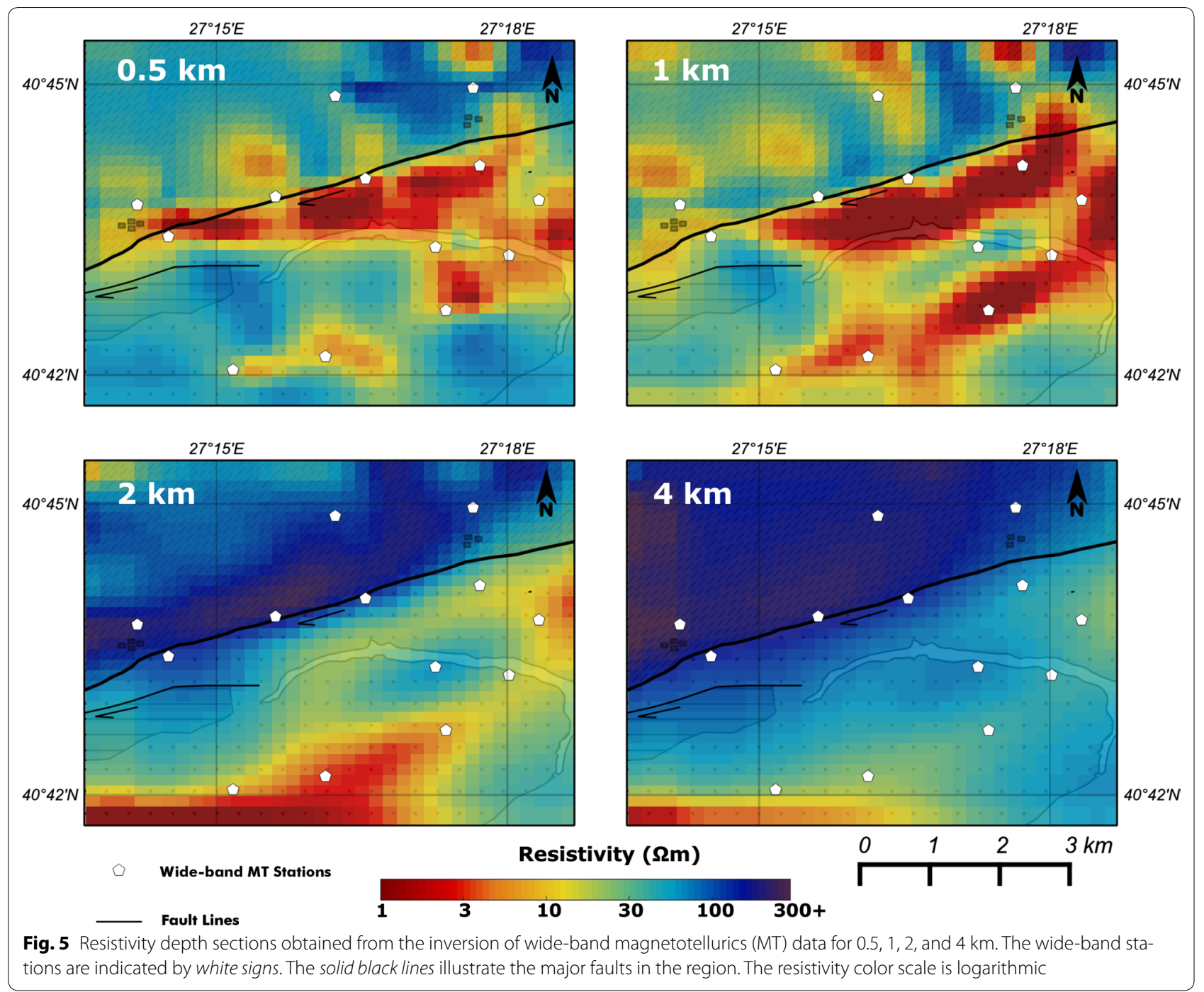

proposed subsidiary branch starting at the central conductor $\left(C_{c}\right.$; Figs. $\left.5,6 \mathrm{c}\right)$ and ending near Gaziköy (Aksoy et al. 2010). This central conductor is located, where the highest lateral conductance (Fig. 6e) and $\beta$ values (Fig. 3) are observed. Moving westward from this anomaly, the FZC characteristics start to change, both in depth extent and conductivity, suggesting a different type of geological setting. Considering that this zone was also marked as the maximum rupture of the 1912 Mürefte Earthquake (Aksoy et al. 2010; Meghraoui et al. 2012), further geological discussion is required to improve the understanding of the importance of this relatively large conductive area. Tank (2012) compared the FZCs of the seismically active İzmit-Adapazari Fault (IAF) and İznik-Mekece Fault (IMF), representing seismic gaps. Although both faults share the same fluid source in the seismogenic zone (Tank et al. 2005), the shallow structure has different attributes, which are associated with the seismicity and related deformation. The FZC properties of two profiles along the IMF differ, which might be related to local geological features. Our findings also suggest that the homogeneous FZC conductance along the fault in fluid-rich zones is questionable because the variation occurs in rather small distance intervals (Figs. 5, 6). However, the depth of the FZC might provide a better interpretation of the seismicity, where it controls the rheological response of fault zones.

In our resistivity models, the damage zone of the GF is widely distributed over conductive areas. Based on faultfluid flow models of Caine et al. (1996), it is unlikely to observe barrier-like mechanisms at the GF because the damage zone is too broad to be compared with the core width. Hence, the fluid transfer around the GF can be classified as distributed conduit in reference to its spatial 


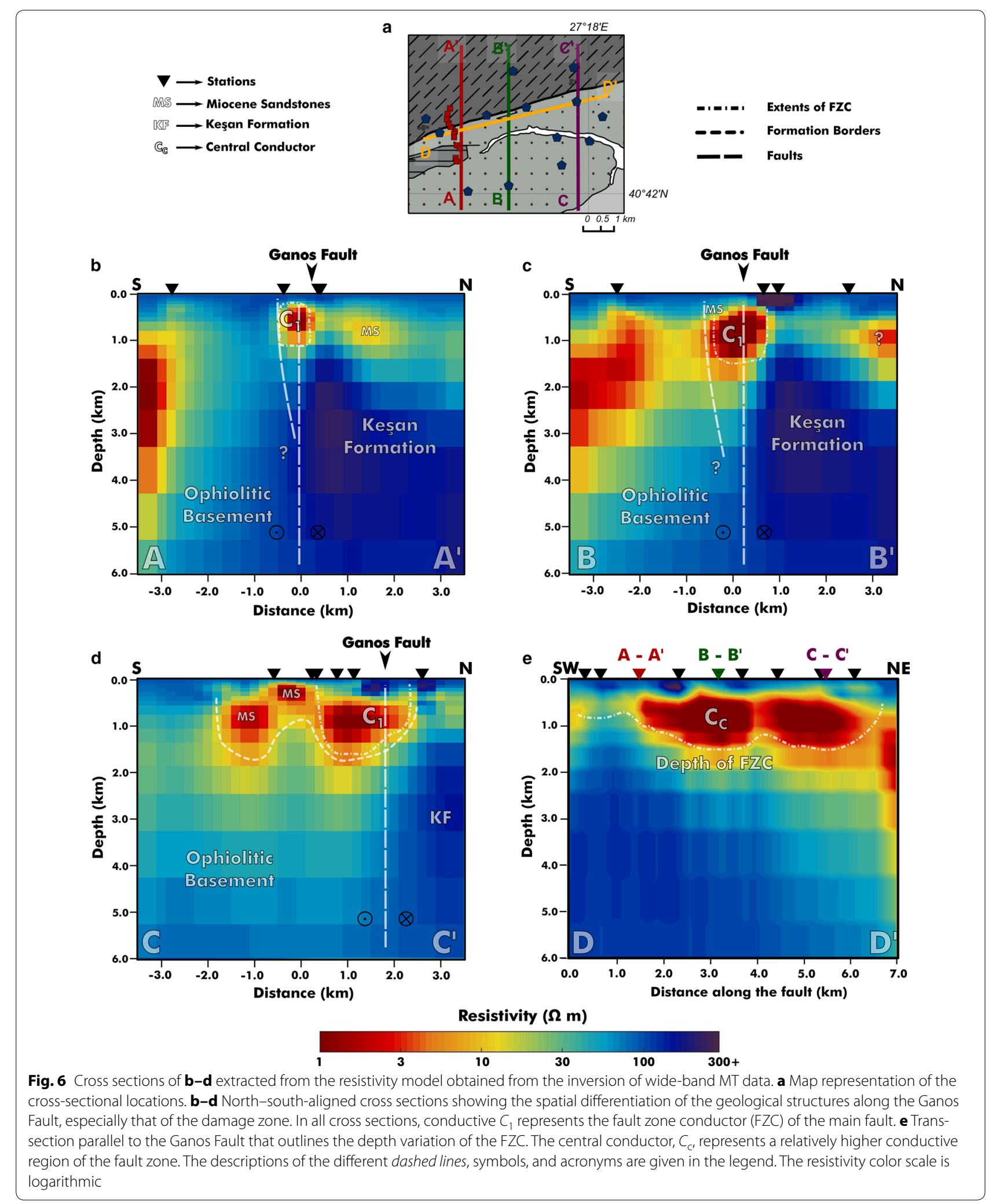




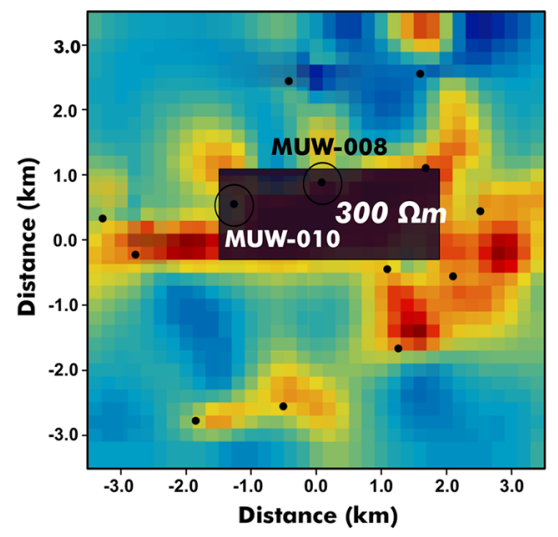

$\mathbf{Z}_{\mathbf{x x}}$

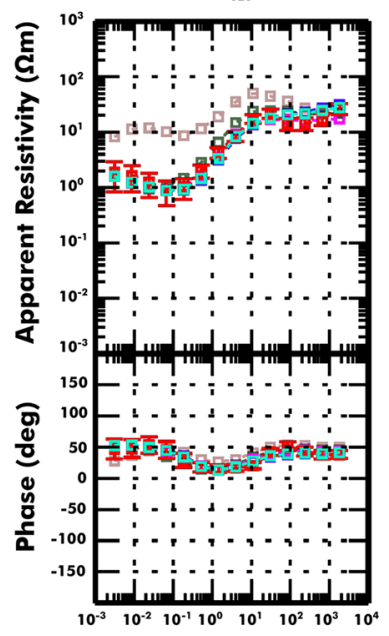

$\mathbf{Z}_{\mathbf{x x}}$

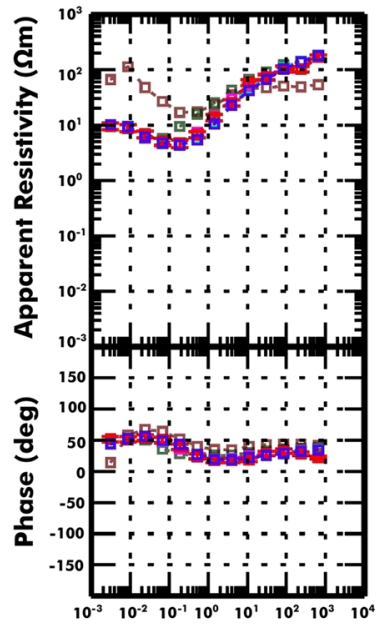

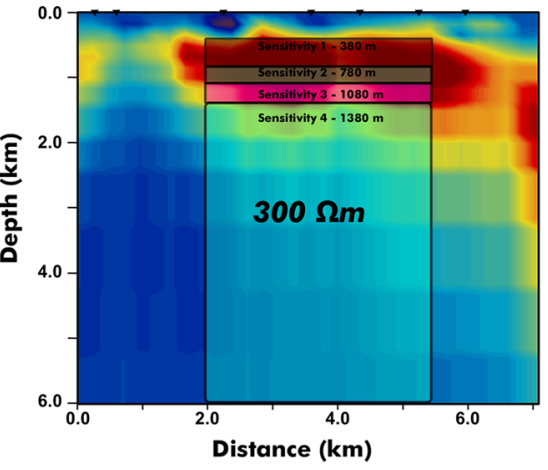

MUW-008

$\mathbf{z}_{\mathbf{x y}}$

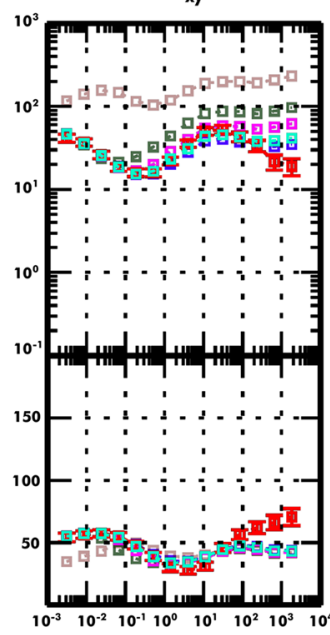

$\mathbf{Z}_{\mathbf{y x}}$

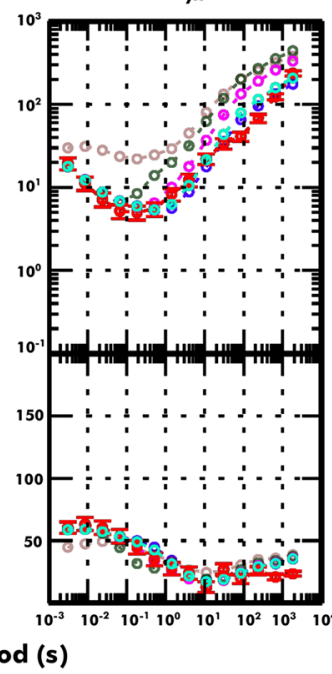

$\mathbf{Z}_{\mathbf{y x}}$

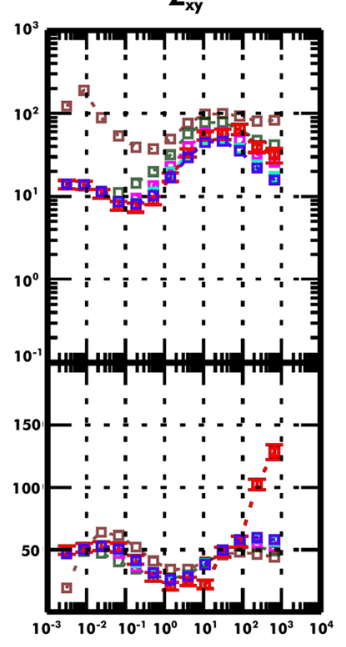

MUW-010

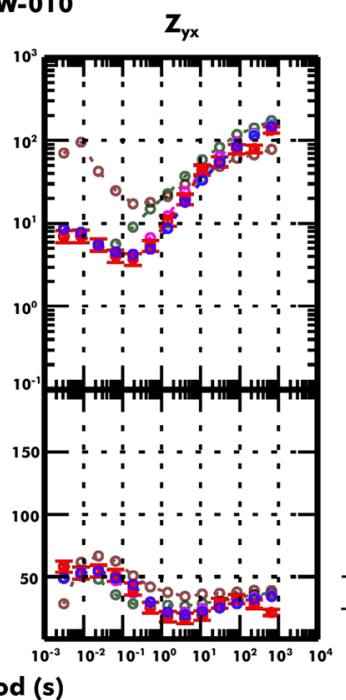

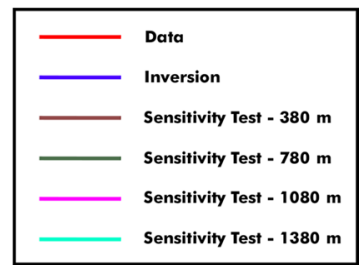

$\mathbf{z}_{\mathrm{yy}}$

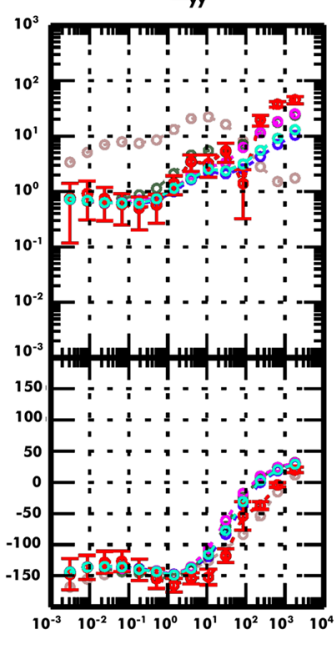

$\mathbf{z}_{\mathbf{y y}}$

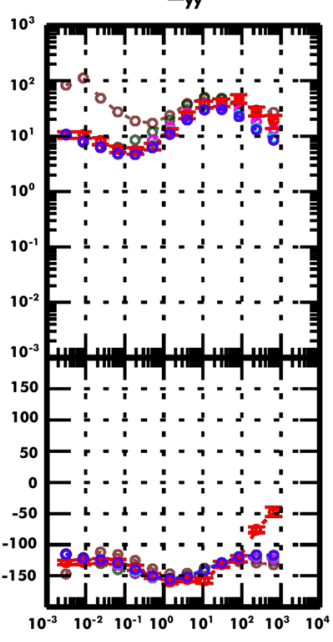

Fig. 7 Sensitivity test to determine the thickness of the fault zone conductor (FZC). A resistive block $(300 \Omega \mathrm{m})$ is inserted instead of the FZC at different levels: 1380, 1080, 780, and $380 \mathrm{~m}$. The forward responses were calculated and compared with final model responses. Based on the test, the depth of the FZC ranges between $\sim 800$ and $1000 \mathrm{~m}$ 
extension. Janssen et al. (2009) suggested that the damage zone of the GF is composed of anastomosing strands of fault gouges instead of a continuous main fault based on observations at the Carboneras Fault (CF) in Spain (Faulkner et al. 2003). Although it is hard to resolve the subsidiary gouge layers based on the resistivity models, high electrical anisotropy levels should be observed all around the study area to confirm such a model. This was previously suggested by Ritter et al. (2005) based on a study of the Waterberg Fault, Namibia (Weckmann et al. 2003). In this study, the stability of geoelectric strike directions in different decades calculated based on phase tensor analyses using wide-band data clarified that there is no evidence for such levels of anisotropy at the GF (Fig. 2b). In addition to low levels of anisotropy, the fact that the FZC of the main fault is rather dominant relative to subsidiary FZCs, we suggest that the fault zone structure of the GF is similar to that of the Punchbowl Fault (PF), Southern California (Schulz and Evans 2000), rather than the CF, in terms of both geometrical positioning and density of fractures.

The damage zone of the GF is asymmetrical around the axes determined by the core alignment and almost exclusively concentrated south of these axes. The asymmetric damage zones show a mechanical strength contrast between two sides of faults depending on the lithology of relevant geological structures (Ritter et al. 2005). This strength contrast is due to poorly lithified Miocene sandstones in the south and consolidated Eocene sandstoneshale intercalation called Keșan Formation in the north (Okay et al. 2010). This strength contrast might create a plausible environment for the creation of an asymmetric damage zone at shallow depths. The distinguishing and similar characteristic of the PF and GF is an asymmetry due to multiple damage zones that overlap each other. However, fractures in the vicinity of the PF are more densely distributed than subsidiary faults around the GF; thus, a wide, interconnected gouge system is not developed. Auxiliary faults in the study area were suggested by Yaltırak and Alpar (2002) and Okay et al. (2010); the conductive $\mathrm{C} 2$ anomaly represents the most prominent subsidiary fault in the south of the GF (Fig. 4). The damage zones of these faults merge into conductive areas, forming a negative flower structure around the GF. However, this large weakness area reaches a maximum only at $\sim 1200 \mathrm{~m}$ depth, verifying the position of a mechanically stronger protolith, which corresponds to the ophiolitic basement (Fig. 6c).

Earthquake activity in fault systems tends to be concentrated near conductive-resistive interfaces, frequently on the resistive side, as previously detected in many other MT studies (Unsworth et al. 1997, 1999; Ogawa et al. 2001; Mitsuhata et al. 2001; Bedrosian et al. 2002; Goto et al. 2005; Tank et al. 2005; Gürer and Bayrak 2007). This is due to the reduction of the effective normal stress or rheological alteration at the boundary by fluid migration from conductive zones through resistive blocks (Wannamaker et al. 2004). Local earthquakes are distributed just north of the GF; some outliers can be found south of our study area. However, such a conceptual consideration is not recommended due to the lack of seismic and microseismic event records (Janssen et al. 2009; Öztürk et al. 2015). Here, the earthquake occurrence rate gradually decays from the Marmara Sea to the terrestrial GF (Fig. 1a). In the Gaziköy-Mursallı region, several oblique-thrust systems surround the GF (Kalafat 1995; Yaltırak and Alpar 2002; Okay et al. 2004); most of the earthquakes were probably generated by these subsidiary faults rather than by the main fault.

Wide-band MT models confirm that fluid pathways were not derived from greater depths, which contributes to the fluid supply in the shallow fault zone. Hence, the FZC of the fault must consist of fluids of meteoric origin as previously suggested by Janssen et al. (2009) based on geochemical analyses. Meteoric fluids in the vicinity of the fault are entrapped by poorly lithified Miocene sandstone that acts as reservoir and occurs in highly conductive areas (Figs. 4, 5). The GF juxtaposes the resistive northern rocks with conductive and mechanically weak formations in shallower areas. However, the resistivity contrast diminishes with depth and highly resistive blocks start to stand out on both sides of the fault, which indicates the absence of fluids that contribute additional pressure to the stress equilibrium of the fault. Without any fluid-assisted weakening, stable formations can maintain the frictional stress of asperities (Brodsky and Kanamori 2001) and form an environment favorable for an anomalously inactive locked fault. We suggest that the scarce seismic activity of the main fault might be explained by fault-fluid relations observed in this segment, characterized by the absence of fluid flow into the fault zone at seismogenic depths. The electrical properties of the region elucidated from the results mentioned above are summarized in our conceptual tectonic sketch (Fig. 8). A more detailed investigation targeting greater depths should be carried out to determine the effect of fluids on the seismicity of the GF.

\section{Conclusion}

In this study, AMT and wide-band MT data were collected for the GF in the vicinity of the epicenter of the 1912 Mürefte Earthquake $\left(M_{\mathrm{w}}=7.4\right)$. Dimensionality analysis and three-dimensional inversion of both datasets revealed the conductivity structure and yielded the results given in the conceptual model (Fig. 8). Performing $3 \mathrm{D}$ analysis allowed us to detect highly varying lateral 


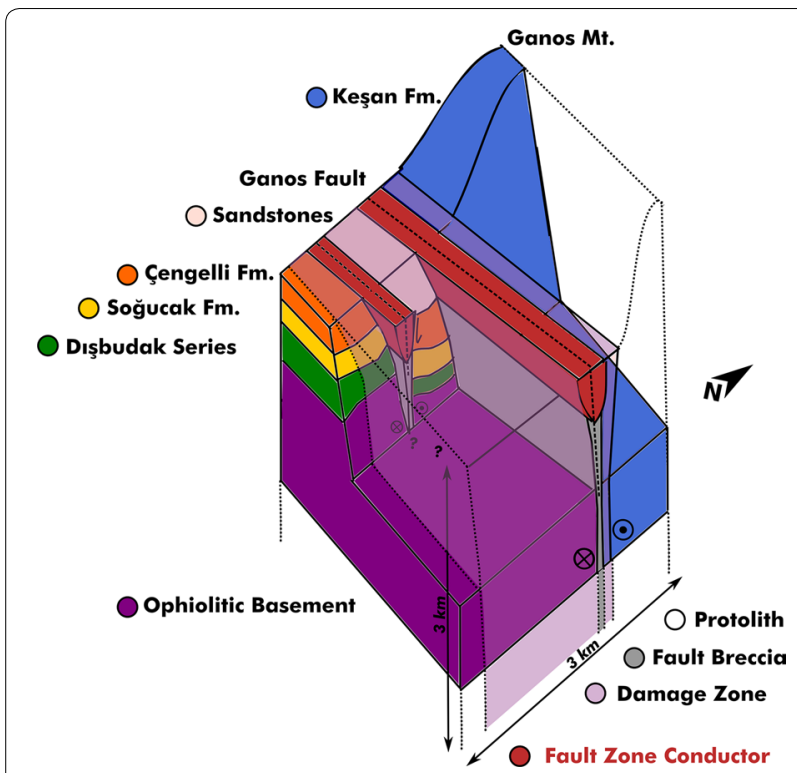

Fig. 8 Conceptual sketch of geological interpretations of the results of the magnetotelluric study. A fluid-bearing asymmetric damage zone representative of resistivity models is drawn around the Ganos Fault. The potential flower structure formed by the main strand and the oblique subsidiary fault in the south are illustrated

conductance values along the GF. The GF consists of several subsidiary fracture zones surrounding the main fault, which were identified by individual FCZs. The damage zone of the GF extends widely along these FZCs, forming an asymmetric damage zone concentrated in the south, where the younger formations act as reservoir for meteoric water. These spatial characteristics demonstrate a distributed conduit behavior of fluid flow in the vicinity of the GF. The GF is a strike-slip fault, almost lacking a dipping component. The geoelectric strike angles are in agreement with the geological strike angles and follow a $\mathrm{N} 70^{\circ} \mathrm{E}$ trend. The absence of fluid pathways at greater depths and mechanically strong and resistive media on both sides of the fault might be indicators of the locked state of the fault, indicating a great potential for generating a large earthquake in the future.

\section{Additional file}

Additional file 1. Supplementary materials.

\section{Authors' contributions}

MK collected data, participated in the design of the study, and helped draft the manuscript. SBT collected data, participated in the design of the study, performed statistical analysis, and helped draft the manuscript. SÖ performed statistical analysis and helped draft the manuscript. All authors read and approved the final manuscript.

\section{Author details}

${ }^{1}$ Kandilli Observatory and Earthquake Research Institute, Boğaziçi University, Istanbul, Turkey. ${ }^{2}$ Faculty of Mines, Department of Geophysics, İstanbul Technical University, İstanbul, Turkey.

\section{Acknowledgements}

This study was supported by Boğaziçi University Research Funds (BAP; Grant $\#$ 10080). Constructive comments of the editors Prasanta K. Patro and Yasuo Ogawa and two anonymous reviewers improved the manuscript. We are also thankful for constructive reviews by Aral I. Okay and Aysu Ceren Okur. We express our gratitude to Gary Egbert and Weerechai Siripunvaraporn for providing the 3D inversion codes (ModEM and WSINV3DMT). The MTpy package (Krieger and Peacock 2007) was extensively used during the study. We are grateful to Lars Krieger and Jared R. Peacock for their support. The strike code was provided by Alan G. Jones.

\section{Competing interests}

The authors declare that they have no competing interests.

\section{Publisher's Note}

Springer Nature remains neutral with regard to jurisdictional claims in published maps and institutional affiliations.

Received: 3 January 2017 Accepted: 31 July 2017

Published online: 15 August 2017

\section{References}

Aksoy ME, Meghraoui M, Vallée M, Çakir Z (2010) Rupture characteristics of the AD 1912 Mürefte (Ganos) earthquake segment of the North Anatolian fault (western Turkey). Geology 38(11):991-994

Ambraseys N (2002) The seismic activity of the Marmara Sea region over the last 2000 years. Bull Seismol Soc Am 92(1):1-18

Ambraseys NN, Finkel CF (1987) The Saros-Marmara earthquake of 9 August 1912. Earthq Eng Struct Dyn 15(2):189-211

Becken M, Ritter O (2012) Magnetotelluric studies at the San Andreas Fault Zone: implications for the role of fluids. Surv Geophys 33(1):65-105

Becken M, Ritter O, Park SK, Bedrosian PA, Weckmann U, Weber M (2008) A deep crustal fluid channel into the San Andreas Fault system near Parkfield, California. Geophys J Int 173(2):718-732

Becken M, Ritter O, Bedrosian PA, Weckmann U (2011) Correlation between deep fluids, tremor and creep along the central San Andreas fault. Nature 480(7375):87-90

Bedrosian PA, Unsworth MJ, Egbert G (2002) Magnetotelluric imaging of the creeping segment of the San Andreas Fault near Hollister. Geophys Res Lett 29(11):1506-1509

Bedrosian PA, Unsworth MJ, Egbert GD, Thurber CH (2004) Geophysical images of the creeping segment of the San Andreas fault: implications for the role of crustal fluids in the earthquake process. Tectonophysics 385(1):137-158

Brodsky EE, Kanamori H (2001) Elastohydrodynamic lubrication of faults. J Geophys Res Solid Earth 106(B8):16357-16374

Byerlee JD (1993) Model for episodic flow of high-pressure water in fault zones before earthquakes. Geology 21(4):303-306

Caine JS, Evans JP, Forster CB (1996) Fault zone architecture and permeability structure. Geology 24(11):1025-1028

Caldwell TG, Bibby HM, Brown C (2004) The magnetotelluric phase tensor. Geophys J Int 158(2):457-469

Egbert GD, Kelbert A (2012) Computational recipes for electromagnetic inverse problems. Geophys J Int 189(1):251-267

Electromagnetic Research Group for the Active Fault (1982) Low electrical resistivity along an active fault. J Geomagn Geoelectr 34:103-127

Evans JP (1990) Thickness-displacement relationships for fault zones. J Struct Geol 12(8):1061-1065

Faulkner DR, Lewis AC, Rutter EH (2003) On the internal structure and mechanics of large strike-slip fault zones: field observations of the Carboneras fault in southeastern Spain. Tectonophysics 367(3):235-251 
Gamble T, Goubau WM, Clarke J (1979) Magnetotellurics with a remote magnetic reference. Geophysics 44(1):53-68

Goto TN, Wada Y, Oshiman N, Sumitomo N (2005) Resistivity structure of a seismic gap along the Atotsugawa Fault, Japan. Phys Earth Planet Inter 148(1):55-72

Groom RW, Bailey RC (1989) Decomposition of magnetotelluric impedance tensors in the presence of local three-dimensional galvanic distortion. Geophys Res Solid Earth 94(B2):1913-1925

Gürer A, Bayrak M (2007) Relation between electrical resistivity and earthquake generation in the crust of West Anatolia, Turkey. Tectonophysics 445(1):49-65

Hickman S, Sibson R, Bruhn R (1995) Introduction to special section: mechanical involvement of fluids in faulting. J Geophys Res Solid Earth 100(B7):12831-12840

Hoffmann-Rothe A, Ritter O, Janssen C (2004) Correlation of electrical conductivity and structural damage at a major strike-slip fault in northern Chile. J Geophys Res Solid Earth 109(B10):1-17

Honkura Y, Işikara AM, Oshiman N, Ito A, Üçer B, Bariş Ş, Tunçer MK, Matsushima M, Pektaş R, Çelik C, Tank SB, Takahashi F, Nakanishi M, Yoshimura R, Ikeda Y, Komut T (2000) Preliminary results of multidisciplinary observations before, during and after the Kocaeli (Izmit) earthquake in the western part of the North Anatolian Fault Zone. Earth Planets Space 52(4):293-298. doi:10.1186/BF03351638

Honkura Y, Oshiman N, Matsushima M, Bariş Ş, Tunçer MK, TankSB, Çelik C, Çiftçi ET (2013) Rapid changes in the electrical state of the 1999 Izmit earthquake rupture zone. Nat Commun 4:1-10

Irwin WP, Barnes I (1975) Effect of geologic structure and metamorphic fluids on seismic behavior of the San Andreas fault system in central and northern California. Geology 3(12):713-716

Janssen C, Bohnhoff M, Vapnik Y, Görgün E, Bulut F, Plessen B, Pohl D, Aktar M, Okay Al, Dresen G (2009) Tectonic evolution of the Ganos segment of the North Anatolian Fault (NW Turkey). J Struct Geol 31(1):11-28

Jiracek GR (1995) Geoelectromagnetics charges on. Rev Geophys 33(S1):169-176

Jödicke H (1992) Water and graphite in the Earth's crust—an approach to interpretation of conductivity models. Surv Geophys 13(4-5):381-407

Johnson PA, McEvilly TV (1995) Parkfield seismicity: fluid-driven? J Geophys Res Solid Earth 100(B7):12937-12950

Kalafat D (1995) Study of the tectonic structures in Anatolia based on fault mechanism solutions. PhD thesis, University of Istanbul, 217 pp. (in

\section{Turkish)}

Kaufman AA, Keller GV (1981) The magnetotelluric sounding method. Elsevier, Amsterdam

Kaya T, Tank SB, Tunçer MK, Rokoityansky II, Tolak E, Savchenko T (2009) Asperity along the North Anatolian Fault imaged by magnetotellurics at Düzce, Turkey. Earth Planets Space 61(7):871-884. doi:10.1186/ BF03353198

Kaya T, Kasaya T, Tank SB, Ogawa Y, Tunçer MK, Oshiman N, Honkura Y, Matsushima M (2013) Electrical characterization of the North Anatolian Fault Zone underneath the Marmara Sea, Turkey, by ocean bottom magnetotellurics. Geophys J Int 193(2):664-677

Kelbert A, Meqbel N, Egbert GD, Tandon K (2014) ModEM: a modular system for inversion of electromagnetic geophysical data. Comput Geosci 66:40-53

Krieger L, Peacock JR (2014) MTpy: a Python toolbox for magnetotellurics. Comput Geosci 72:167-175

Ledo J (2005) 2-D versus 3-D magnetotelluric data interpretation. Surv Geophys 26(5):511-543

McNeice GW, Jones AG (2001) Multisite, multifrequency tensor decomposition of magnetotelluric data. Geophysics 66(1):158-173

Meghraoui M, Aksoy ME, Akyüz HS, Ferry M, Dikbaş A, Altunel E (2012) Paleoseismology of the North Anatolian fault at Güzelköy (Ganos segment, Turkey): Size and recurrence time of earthquake ruptures west of the Sea of Marmara. Geochem Geophys Geosyst 13(4):1-26

Meqbel N, Weckmann U, Muñoz G, Ritter O (2016) Crustal metamorphic fluid flux beneath the Dead Sea Basin: constraints from 2D and 3D magnetotelluric modelling. Geophys J Int 207(3):1609-1629

Mitsuhata Y, Ogawa Y, Mishina M, Kono T, Yokokura T, Uchida T (2001) Electromagnetic heterogeneity of the seismogenic region of 1962 M6.5 Northern Miyagi Earthquake, northeastern Japan. Geophys Res Lett 28(23):4371-4374
Motagh M, Hoffmann J, Kampes B, Baes M, Zschau J (2007) Strain accumulation across the Gazikoy-Saros segment of the North Anatolian Fault inferred from Persistent Scatterer Interferometry and GPS measurements. Earth Planet Sci Lett 255(3):432-444

Ogawa Y, Mishina M, Goto T, Satoh H, Oshiman N, Kasaya T, Takahashi Y, Nishitani T, Sakanaka S, Uyeshima M, Takahashi Y, Honkura Y, Matsushima M (2001) Magnetotelluric imaging of fluids in intraplate earthquake zones, NE Japan back arc. Geophys Res Lett 28(19):3741-3744

Okay Al, Demirbağ E, Kurt H, Okay N, Kuşçu I (1999) An active, deep marine strike-slip basin along the North Anatolian Fault in Turkey. Tectonics 18(1):129-147

Okay Al, Tüysüz O, Kaya Ş (2004) From transpression to transtension: changes in morphology and structure around a bend on the North Anatolian Fault in the Marmara region. Tectonophysics 391 (1):259-282

Okay Al, Özcan E, Cavazza W, Okay N, Less G (2010) Basement types, Lower Eocene series, Upper Eocene olistostromes and the initiation of the southern Thrace Basin, NW Turkey. Turk J Earth Sci 19(1):1-25

Oshiman N, Honkura Y, Matsushima M, Baris S, Celik C, Tuncer MK, Işikara AM (2002) Deep resistivity structure around the fault associated with the 1999 Kocaeli earthquake, Turkey. In: Fujinawa Y, Yoshida A (eds) Seismotectonics in convergent plate boundary. Terra Scientific Publishing Company, Tokyo, pp 293-303

Özcan E, Less G, Okay Al, Báldi-Beke M, Kollányi K, Yilmaz IÖ (2010) Stratigraphy and larger foraminifera of the Eocene shallow-marine and olistostromal units of the southern part of the Thrace Basin, NW Turkey. Turk J Earth Sci 19(1):27-77

Öztürk YK, Özel NM, Özbakir AD (2015) States of local stresses in the Sea of Marmara through the analysis of large numbers of small earthquakes. Tectonophysics 665:37-57

Parkinson WD (1959) Directions of rapid geomagnetic fluctuations. Geophys J Int 2(1):1-14

Parsons T, Toda S, Stein RS, Barka A, Dieterich JH (2000) Heightened odds of large earthquakes near Istanbul: an interaction-based probability calculation. Science 288(5466):661-665

Patro PK, Egbert GD (2011) Application of 3D inversion to magnetotelluric profile data from the Deccan Volcanic Province of Western India. Phys Earth Planet Inter 187(1):33-46

Ritter O, Hoffmann-Rothe A, Bedrosian PA, Weckmann U, Haak V (2005) Electrical conductivity images of active and fossil fault zones. Geol Soc Lond Spec Publ 245(1):165-186

Rockwell T, Barka A, Dawson T, Akyuz S, Thorup K (2001) Paleoseismology of the Gazikoy-Saros segment of the North Anatolia fault, northwestern Turkey: comparison of the historical and paleoseismic records, implications of regional seismic hazard, and models of earthquake recurrence. J Seismol 5(3):433-448

Schulz SE, Evans JP (2000) Mesoscopic structure of the Punchbowl Fault, Southern California and the geologic and geophysical structure of active strike-slip faults. J Struct Geol 22(7):913-930

Seeber L, Emre O, Cormier MH, Sorlien CC, McHugh CMG, Polonia A, Ozer N, Cagatay N (2004) Uplift and subsidence from oblique slip: the GanosMarmara bend of the North Anatolian Transform, Western Turkey. Tectonophysics 391(1):239-258

Şengör AMC, Tüysüz O, Imren C, Sakinç M, Eyidogan H, Görür N, Le Pichon X, Rangin C (2005) The North Anatolian fault: a new look. Annu Rev Earth Planet Sci 33:37-112

Siripunvaraporn W (2012) Three-dimensional magnetotelluric inversion: an introductory guide for developers and users. Surv Geophys 33(1):5-27

Siripunvaraporn W, Egbert G, Uyeshima M (2005a) Interpretation of twodimensional magnetotelluric profile data with three-dimensional inversion: synthetic examples. Geophys J Int 160(3):804-814

Siripunvaraporn W, Egbert G, Lenbury Y, Uyeshima M (2005b) Three-dimensional magnetotelluric inversion: data-space method. Phys Earth Planet Inter 150(1):3-14

Tank SB (2012) Fault zone conductors in Northwest Turkey inferred from audio frequency magnetotellurics. Earth Planets Space 64(9):729-742. doi:10.5047/eps.2012.02.001

Tank SB, Honkura Y, Ogawa Y, Oshiman N, Tunçer MK, Matsushima M, Çelik C, Tolak E, Işikara AM (2003) Resistivity structure in the western part of the fault rupture zone associated with the 1999 Izmit earthquake and its seismogenic implication. Earth Planets Space 55(7):437-442. doi:10.1186/ BF03351777 
Tank SB, Honkura Y, Ogawa Y, Matsushima M, Oshiman N, Tunçer MK, Çelik C, Tolak E, Işikara AM (2005) Magnetotelluric imaging of the fault rupture area of the 1999 Izmit (Turkey) earthquake. Phys Earth Planet Inter 150(1):213-225

Thomas AM, Nadeau RM, Bürgmann R (2009) Tremor-tide correlations and near-lithostatic pore pressure on the deep San Andreas fault. Nature 462(7276):1048-1051

Türkoğlu E, Unsworth M, Çağlar I, Tuncer V, Avşar Ü (2008) Lithospheric structure of the Arabia-Eurasia collision zone in eastern Anatolia: magnetotelluric evidence for widespread weakening by fluids? Geology 36(8):619-622

Tüysüz O, Barka A, Yiğitbaş E (1998) Geology of the Saros graben and its implications for the evolution of the North Anatolian fault in the Ganos-Saros region, northwestern Turkey. Tectonophysics 293(1):105-126

Unsworth MJ, Bedrosian PA (2004) Electrical resistivity structure at the SAFOD site from magnetotelluric exploration. Geophys Res Lett 31(12):1-4

Unsworth MJ, Malin PE, Egbert GD, Booker JR (1997) Internal structure of the San Andreas fault at Parkfield. Calif Geol 25(4):359-362

Unsworth MJ, Egbert G, Booker J (1999) High-resolution electromagnetic imaging of the San Andreas fault in central California. J Geophys Res Solid Earth 104(B1):1131-1150

Unsworth MJ, Bedrosian P, Eisel M, Egbert G, Siripunvaraporn W (2000) Along strike variations in the electrical structure of the San Andreas Fault at Parkfield, California. Geophys Res Lett 27(18):3021-3024
Vozoff K (1972) The magnetotelluric method in the exploration of sedimentary basins. Geophysics 37(1):98-141

Wannamaker PE, Caldwell TG, Doerner WM, Jiracek GR (2004) Fault zone fluids and seismicity in compressional and extensional environmen inferred from electrical conductivity: the New Zealand Southern Alps and US Great Basin. Earth Planets Space 56(12):1171-1176. doi:10.1186/ BF03353336

Wannamaker PE, Caldwell TG, Jiracek GR, Maris V, Hill GJ, Ogawa Y, Bibby HM, Bennie SL, Heise W (2009) Fluid and deformation regime of an advancing subduction system at Marlborough, New Zealand. ature 460(7256):733-736

Weckmann U, Ritter O, Haak V (2003) A magnetotelluric study of the Damara Belt in Namibia: 2. MT phases over 90 reveal the internal structure of the Waterberg Fault/Omaruru Lineament. Phys Earth Planet Inter 138(2):91-112

Yaltırak C, Alpar B (2002) Kinematics and evolution of the northern branch of the North Anatolian Fault (Ganos Fault) between the Sea of Marmara and the Gulf of Saros. Mar Geol 190(1):351-366

Zattin M, Okay Al, Cavazza W (2005) Fission-track evidence for late Oligocene and mid-Miocene activity along the North Anatolian Fault in southwestern Thrace. Terra Nova 17(2):95-101

Zhang X, Sanderson DJ, Barker AJ (2002) Numerical study of fluid flow of deforming fractured rocks using dual permeability model. Geophys J Int 151(2):452-468

\section{Submit your manuscript to a SpringerOpen ${ }^{\circ}$ journal and benefit from:}

- Convenient online submission

- Rigorous peer review

- Open access: articles freely available online

- High visibility within the field

- Retaining the copyright to your article

Submit your next manuscript at $>$ springeropen.com 